\title{
Educational Standard of Pregnant Women and Their Response to Safe Motherhood Initiative in Orlu Urban, Imo State
}

\author{
Ojinma C.C ${ }^{1}$, And Q.N. John-Nwosu ${ }^{2}$ \\ ${ }^{1}$ Department of Geography, ${ }^{2}$ Department. of Health \\ Alvan Ikoku Federal College of Education, Owerri, Imo State, Nigeria.
}

\begin{abstract}
It is widely expected and indeed believed that when a pregnant mother has attained a certain level of education, her attitude to issues relating to the pregnancy will be factually informed. It is based on this belief that this work sets out to find out if educated pregnant woman have significantly different attitude to SafeMotherhood Initiative (SMI) than the less educated pregnant women in Orlu Urban, Imo State. The Exploratory and Descriptive cross sectional survey design was adopted. Questionnaire was designed to elicit the required information based on the research questions and objectives using a 4 point Likert-Scale. Our ANOVA test was a return of NO statistical significance at 0.05 level. The implication of this study in general is that greater room still exists for advocacy and enlightenment by the various related Ministries and NGOS to ensure that the lives of pregnant women are secured and guaranteed in Imo State.
\end{abstract}

Keywords : Safe Motherhood Initiative-SMI, Pregnancy, Educational Standard,

\section{Introduction}

Maternal Morbidity and Mortality (MMM) which is regarded as a diseased state and death of a woman within forty-two (42) days after termination of pregnancy or within the pregnant period due to causes related to or aggravated by pregnancy or its management (Sach, 1987) is said to be highest in Nigeria during the 80s and 90s decades (Udeinya, 1995; WHO 1980). During the 2000s, it has not reduced as MMM every year globally still reaches over half a million (WHO 2006).

It was as a result of the high MMM that Governments, International Agencies such as (WHO), UNICEF, UNFPA and other Non-governmental Organizations (NGOs) launched the World wide Safe Motherhood Initiative (SMI) at Nairobi (Kenya) in 1987 (Onuzulike, 2006). SMI represents therefore a global effort to reduce MMM in developing countries especially. This Initiative has various components, which include - prenatal care; Ante-natal care; Nutrition; Family planning; Personal hygiene during pregnancy; Essential obstetrics care; Emergency care; Postpartum care; Post-abortion care; Prevention of Sexually transmitted Infections (SMI's) Prevention of Mother to Child transmission of HIV and AIDS and Child care.

According to Mclaren (1994), most of the pregnancy complications and problems that pregnant women experience are deeply rooted in poor responses towards Safe Motherhood Initiative Components, especially Prenatal care, obstetrics care and family planning in Urban and Rural areas of most developing countries. Hence SMI has focused its strategies on expanding and strengthening Maternal health Services; increasing access to family planning services and improving women access to educational economic opportunities.

Our casual observation in Orlu Urban, irrespective of all the efforts of SMI and its strategies is that most pregnant women do attend pre-natal and ante-natal calls but during the actual delivery they will go to any of the public hospitals, private hospitals, Maternities, MCH and TBAs. what comes to mind therefore is whether pregnant women can be differentiated in attendance to these facilities or response to SMI components by any recognizable criteria. For instance, could the preference and responses to such components of SMI be based on education, such that the more educated a pregnant woman is, the more the inclination to more SMI prevalent facilities.

This and other related issues are considered in the succeeding parts of this paper. The next section presents the data for this study.

\section{Data Collection}

The study focused on both the various facilities in Orlu Urban and the number of respondents that attend such facilities on the day of the interview in 2009, the study year. Orlu Urban has one teaching hospital with 82 pregnant women in attendance; 7 Maternity and Child Homes, with 62 pregnant women and 3 Traditional Birth Attendants with 88 pregnant women, making a total sample population of 232 people. The indication is that the greater number of pregnant women still visit the teaching hospital followed by the TBAs. The data was collected with the use of questionnaires based on the 4 point Likert scale of (SA; A; D; SD) (JohnNwosu, 2011). 
Firstly, we subjected the responses of the pregnant women based on their level of Education to analysis based on the Standard Mean Score of 2.5 (which we considered as our criterion mean) and we sought for differences in responses from the various levels of Education using the Analysis of Variance test (ANOVA).

Table I:Education-level Based Responses to SMI $(\mathbf{n}=\mathbf{2 3 2})$

\begin{tabular}{|c|c|c|c|c|c|c|c|c|c|}
\hline \multirow[t]{2}{*}{$\mathbf{S} / \mathbf{N}$} & \multirow[t]{2}{*}{ ITEMS } & \multicolumn{2}{|c|}{ No Formal Edu. } & \multicolumn{2}{|c|}{ Primary Edu. } & \multicolumn{2}{|c|}{ Secondary Edu } & \multicolumn{2}{|c|}{ Tertiary Edu. } \\
\hline & & $\bar{x}$ & SD & $\bar{x}$ & SD & $\bar{x}$ & SD & $\bar{x}$ & SD \\
\hline 1. & Prenatal/Antenatal Care & 2.6 & 0.81 & 2.6 & 0.76 & 2.5 & 0.88 & 2.3 & 0.84 \\
\hline 2. & Nutritional Care & 3.4 & 0.66 & 4.0 & 1.1 & 3.5 & 0.77 & 3.3 & 0.84 \\
\hline 3. & Personal Hygiene & 2.2 & 0.56 & 2.2 & 0.67 & 2.1 & 0.56 & 2.3 & 0.56 \\
\hline 4. & Essential Obstetric Care & 2.5 & 0.86 & 2.5 & 0.58 & $2 . \bar{x}$ & 0.83 & 2.5 & 1.02 \\
\hline 5. & Child Care & 1.6 & 0.76 & 1.8 & 0.80 & 1.8 & 0.80 & 1.8 & 1.00 \\
\hline & Grand Mean & 2.5 & $\mathbf{0 . 7 3}$ & 3.0 & $\mathbf{0 . 7 8}$ & 2.5 & 0.77 & 2.4 & 0.85 \\
\hline
\end{tabular}

Attempts were made to differentiate the various Education levels of pregnant women with a view to $\bar{\varlimsup}$ termine if indeed Educational attainments of pregnant women will influence their responses to the various components of

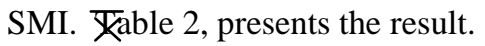

Table 2: Test of Difference in Responses to SMI for Educational Levels.

\begin{tabular}{|c|c|c|c|c|c|c|c|}
\hline $\mathbf{S} / \mathbf{N}$ & SOURCES OF VARIATION & (Items) & $\begin{array}{c}\text { Sum of } \\
\text { Squares (s) }\end{array}$ & $\begin{array}{c}\text { Df } \\
(n-1)\end{array}$ & $\begin{array}{l}\text { Mean } \\
\text { Squares } \\
\text { (MS) }\end{array}$ & $\begin{array}{c}\text { F- } \\
\text { CAL }\end{array}$ & P-Value \\
\hline 1. & $\begin{array}{c}\text { Prenatal/Antenatal Care } \\
, "\end{array}$ & $\begin{array}{l}\text { Btw Groups } \\
\text { Within Groups } \\
\text { Total }\end{array}$ & $\begin{array}{r}10.57 \\
186.72 \\
197.29\end{array}$ & $\begin{array}{r}4 \\
228 \\
231\end{array}$ & $\begin{array}{r}3.5 \\
0.82 \\
4.32\end{array}$ & 3.7 & 0.1 \\
\hline 2. & $\begin{array}{r}\text { Nutritional Care } \\
, \\
,\end{array}$ & $\begin{array}{l}\text { Btw Groups } \\
\text { Within Groups } \\
\text { Total }\end{array}$ & $\begin{array}{r}4.35 \\
162.50 \\
166.85\end{array}$ & $\begin{array}{r}4 \\
228 \\
231\end{array}$ & $\begin{array}{l}1.449 \\
3.564 \\
5.012\end{array}$ & 1.7 & 1.1 \\
\hline 3. & $\begin{array}{r}\text { Personal Hygiene } \\
,, \\
,\end{array}$ & $\begin{array}{l}\text { Btw Groups } \\
\text { Within Groups } \\
\text { Total }\end{array}$ & $\begin{array}{r}4.540 \\
92.5 \\
97.04 \\
\end{array}$ & $\begin{array}{r}4 \\
228 \\
231 \\
\end{array}$ & $\begin{array}{l}1.513 \\
0.406 \\
1.919 \\
\end{array}$ & 2.4 & 0.3 \\
\hline 4. & $\begin{array}{c}\text { Essential Obstetric Care } \\
, \\
,\end{array}$ & $\begin{array}{l}\text { Btw Groups } \\
\text { Within Groups } \\
\text { Total }\end{array}$ & $\begin{array}{r}5.188 \\
207.58 \\
212.67\end{array}$ & $\begin{array}{r}4 \\
228 \\
231 \\
\end{array}$ & $\begin{array}{r}1.730 \\
0.91 \\
2.640\end{array}$ & 2.0 & 1.0 \\
\hline 5. & Child Care & $\begin{array}{l}\text { Btw Groups } \\
\text { Within Groups } \\
\text { Total }\end{array}$ & $\begin{array}{r}10.39 \\
198.91 \\
209.30 \\
\end{array}$ & $\begin{array}{r}4 \\
228 \\
231 \\
\end{array}$ & $\begin{array}{l}3.463 \\
0.872 \\
4.335\end{array}$ & 4.1 & 0.1 \\
\hline
\end{tabular}

(Source: Fieldwork, 2009)

\section{Data Discussion}

From the data we collected and the subsequent tables 1 and 2, it is obvious that the impact of education on the responses of pregnant women to the components of SMI are inconsistent. Table 1 for instance shows that generally, level of educational attainment of pregnant women does not affect their responses. Obviously we expected to observe a consistent rise in responses to SMI components from these pregnant women with No Formal Education to the pregnant women with Tertiary Level Education. What we have seen statistically is a diffused state of affairs. From table 1, the Grand Mean of the various levels reads as follows: Non Formal Education Standard (std) Mean ( ) 2.5; calculated (cal) Mean=2.5 (indicating an acceptable response); Primary Education Level: Std = 2.5; cal = 3.0 (acceptable response); Secondary Education level: Std = 2.5; cal = 2.5 (acceptable response); Tertiary Education level $=\mathrm{Std}=2.5 ;$ cal $=2.4$ (unacceptable response). Indeed, a close observation of the responses to the various SMI components is instructive. Whereas the other levels of education are positively responsive to receiving pre and ante-natal care, the respondents that have tertiary education showed some carelessness. However, it is observed from table I, that among all the SMI components, all levels of the pregnant women shared high and acceptable responses to nutritional care, with the highest being those that attained Primary School level, with a 4.0 level as their mean value, at a standard mean level of 2.5, followed by Secondary level pregnant women (3.5), Non-formal level (3.4) and Tertiary level (with the least mean (3.3). Similar values are observed for Obstetric care, where all the other levels reflected the standard mean value (2.5), except those at the secondary education level that had a marginal increase (2.6). The least response is observed in the component of childcare, where all the levels reflected unacceptable mean values (1.8), the worst being those with Non-formal education (1.6).

The implications of these findings are wide and varied for the reduction or elimination of Maternal Morbidity and Mortality (MMM) among pregnant women in Imo State. A situation where pregnant women with the least level of education are responding more positively than their counterparts with tertiary level education in components of SMI (prenatal and antenatal care, and Nutritional care) leaves much to be desired. It equld also 
reflect the nature of data collected. Since the data did not include pregnant women that patronize private hospitals, it is possible that most of the highly educated pregnant women, visit private hospitals. Even at that, the current data ought to have shown a remarkably high Mean level for Tertiary educationally attained pregnant mothers, who will be expected to know the implications of not taking pre and antenatal care very seriously at pregnancy. This calls for greater awareness to all levels of pregnant women especially the educated mothers.

Given all that we have observed on table I, it is not surprising that in the test of difference (ANOVA) among the varied categories of educated women, (table 2) there was no significant difference at $95 \%$ level. This lack of differences are especially obvious for such components as child care, pre and ante natal care and personal hygiene. We had expected that between group figures for child care and personal hygiene will approximate the table values, but we found the contrary. Hence level of education of pregnant mothers, is completely compromised in activities of pregnant women regarding their consciousness and awareness of the orchestrated high MMM in Nigeria.

\section{What Can Be Done}

It is obvious that whereas all women (at least, in the developing countries desire to have pregnancy and produce children, none of them desires to die or be permanently impaired with pregnancy. Hence they desire to be pregnant, deliver safely and live to cater for the babies. A situation, where these desiresol are not matched with appropriate responses to such initiative as Safe Motherhood activities is like "building castles in the air" According to Udeinya (1995), in "Balanced Theory", people desire cognitive consistency or balance in their thoughts, feelings and relationships. Usually balancing of actions or relationships produces rewards, while imbalancing of activities have unpleasant consequencies. Osgood and Tamenbaum (1954) called the same bahaviour the "principle of congruity". Where an existing frame of references will affect the immediate behaviuor. In this case, if pregnant women are increasingly aware of the consequencies of neglecting SafeMotherhood actions, then the more women get educational attainment, the more pregnant women will take care to implement SafeMotherhood principles and activities. Indeed, it does appear that there is increasing need to include safemotherhood principles in sexuality or population education being taught at schools.

What is observed at present is that residual knowledge and practices gotten from homes of pregnant women irrespective of level of education are what they still practice in Imo State, especially Orlu Urban. This means that most of the educated pregnant women do not attend public or general hospitals where most of the SafeMotherhood practices are taught or lectured during ante-natal care sessions. Hence, in most of the components of SMI, the so-called "illiterate woman" are the ones taking precautions to reduce MMM in Imo state. The more educated pregnant women on their part attend "special and private hospitals" where the trained hospital personnel take care of the essential obstetric cares, while all the other components that are personal to the pregnant women are oversighted (see tables $1 \& 2$ ). What is needed here is that every pregnant women should attempt to learn the principles of SMI and accordingly act to ensure reduction of the MMM.

Again, the pregnant women should not allow the social and economic embarrassments of the current state of the country to prevent them from effecting effective child care. It is painful to observe from the data that child care has the highest unacceptability in our analysis (table 1) and the highest similarity among all educational levels of pregnant women (table 2). The implication is that most pregnant women of all educational categories do not have time to give their babies the deserved care, thereby increasing the discomfort of both mother and child. It is fact that women of all categories are involved in the struggle for survival and meeting with the trends. Pregnant women must attempt to be conversant with the principles of SMI, so as to forestall the high incidence of Maternal Morbidity and Mortality (MMM). This can be achieved through increased advocacy by both international organizations and Non-governmental Organizations associated with Safe Motherhood Initiatives.

\section{Conclusion}

Safe Motherhood Initiative is intended to make pregnancy and delivery a safe experience for women, to reduce and finally eliminate the very rising Maternal Morbidity and Mortality (Onuzulike, 2006; W.H.O 2006). The Initiative has been reduced into components to make evaluation possible.

What we have done is predicated on the assumption that the more a pregnant woman is educated, the more she will be well disposed to appreciating life and living, thus, engage in such SMI actions that will ensure safe delivery during pregnancy and not be part of the ever increasing MMM.

Our analysis however indicated on the contrary that the response of highly educated pregnant women is the same as the response of the non-formally educated and the rest of the educational levels - Primary and Secondary. This situation is pathetic and leaves much to be desired, but certainly needs to be changed.

We have therefore recommended what should be done, to include: Safe Motherhood Initiatives should be taught to pregnant Mothers at General Hospitals during antenatal sessions; SafeMotherhood principles and components should also be included in the sexuality and population Education being taught in schools; Private Hospitals, 
which are mostly the fancy of Tertiary educated pregnant women should incorporate SMI in their treatment procedures; Pregnant women in general should not allow the hassles of the current economic situation of Nigeria to make them overlook the impending danger due to pregnancies, hence they must have time to attend to the requirements of the SMI actions; finally, the International and Non-governmental Organizations should increase their SMI advocacy to various socio-economic, religions and cultural institutions in Imo State in particular and Nigeria in general.

\section{References}

[1] John-Nwosu, Q.N (2011). Attitude of Pregnant Women Towards SafeMotherhood Initiative in Orlu Urban, Imo State. Unpublished M.Sc thesis U.N.N.

[2] Mclaren, S.C (1994). Maternal Safety and Risk Management in Pregnancy. London; Chapman Publishing Co.

[3] Onuzulike, N.M (2006). Issues in Health. Owerri: Mantle Publishers.

[3] Osgood, O. and Tamenbaum, B. (1954). Health Theories and Behaviours in Teenage School Students. Health Education Research Theory and Practice, 21(2)

[4] Udeinya, M. (1995). Safe Motherhood and the Search for improved family Health. London. Allwell Press.

[5] W.H.O (2002). Maternal and Child Care. Geneva: Elserver Pub. Inc.

[6] W.H.O (2006). Safe Motherhood. Geneva Switzerland; Allwell Press. 